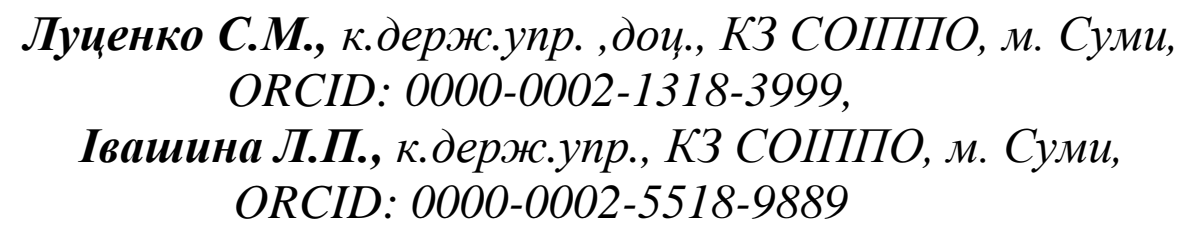

Lutsenko S., candidate of science in public administration, docent, docentthe department of pedagogy, special education and management Public Institution Sumy Regional institute of postgraduate pedagogical education, Sumy

Ivashyna L., candidate of science in public administration, senior lecturer

of the department of pedagogy, special education and management Public Institution Sumy Regional institute of postgraduate pedagogical education, Sumy

\title{
ОСОБЛИВОСТІ ТАЙМ-МЕНЕДЖМЕНТУ ДЕРЖАВНИХ СЛУЖБОВЦІВ В ІНФОРМАЦІЙНОМУ СЕРЕДОВИЩІ
}

\section{FEATURES OF TIME MANAGEMENT OF GOVERNMENT OFFICIALS IN THE INFORMATION ENVIRONMENT}

У статті обтрунтовується актуальність підвищення ефективності управлінської діяльності державного службовия при ефективній організаиії робочого часу, розкривається необхідність впровадження у ній технологій таймменеджменту. Розглядаються погляди щодо застосування технологій таймменеджменту державного службовия, визначаються прості прийоми, які допомагають підвищити продуктивне використання часу державного службовия в інформаційному середовищі.

Ключові слова: тайм-менеджмент, керівник, державний службовеиь, інформачія, управління, час.

The article substantiates the relevance of improving the efficiency of management activities of government officials in the effective organization of working time, reveals the need for the introduction of time management technologies. Views on the use of time management technologies for government servants are considered, simple techniques are identified that help increase the productive use of government official's time in the information environment.

Key words: time management, manager, government official, information, management, time.

Постановка проблеми. Діяльність державних службовців потребує «управління часом», що трактується як раціональний розподіл та ефективне використання часу, тобто формулювати якісне виконання роботи, досягнення поставлених цілей за мінімальний проміжок часу. Завдання державних 
службовцівполягає в мінімізації часу та отримання позитивного результату, оскільки має організувати свою діяльність так, щоб гармонійно поєднати наявні в нього ресурси, в тому числі і часові. Накопичення невирішених завдань породжує емоційне напруження, що може з часом спровокувати стресовий станізменшити продуктивність та якість роботи керівника закладу освіти. Послідовність і своєчасність виконання завдань допомагає знайти час для власних потреб, що в свою чергу робить життя гармонійним.

Аналіз останніх досліджень i публікацій. Питання таймменеджменту державних службовців аналізуються в працях українських вчених таких, як Н. Алюшина, В. Свдокимов, Г. Євтушенко, Н. Заєць, Н. Любченко, Л. Калініченко, М. Кук, С. Павлютенкова, Г. Писаревська, М. Прищак, Л. Скібіцьката інші. Проте невирішеним залишається питання тенденцій тайм-менеджменту державних службовціввінформаційному середовищі.

Метою статті $\epsilon$ аналіз особливостейтайм-менеджменту державних службовціввінформаційному середовищі.

Виклад основного змісту. Поряд із виконанням своїх функціональних обов'язків державні службовці повинні швидко адаптуватися до змін, переосмислити свою управлінську діяльність у відповідності до сучасних тенденцій, розумно розставляти пріоритети управлінських рішень.Таймменеджмент - це техніка управління часом, яка включає в себе правила i принципи, що допомагають людині правильно організувати свій час і досягти максимальної ефективності в будь-якій справі. Прямий переклад даного терміна «timemanagement» 3 англійської повністю передає його сенс і звучить як «управління часом». Тайм-менеджмент допомагає більш ефективно використовувати не тільки робочий час, виконання конкретних завдань, проєктів, цілей, а і організовувативідпочинок. Зокрема, рекомендується не брати роботу додому, організувати побут так, щоб він займав мінімум часу, заздалегідь ретельно планувати вільний час і слідувати цим планам, зокрема регулярно практикувати емоційне і фізичне перемикання тощо.[9].

На думку Г. Свтушенко, тайм-менеджмент - це не тільки правильний розподіл власного часу, а й керування чинниками, які впливають на нього, тобто робоча атмосфера, стосунки з колегами, організація відпочинку, побуту тощо [6]. Час існує незалежно від нас, тому терміни «управління часом» або «тайм-менеджмент»досить умовні. Більшість науковців розглядає таймменеджмент як галузь менеджменту, основне завдання якої полягає у виявленні методів і принципів ефективного управління часом. На думку Н. Заєць, тайм-менеджмент - це вміння управляти собою із застосуванням відповідних методик та механізмів організації часу, які сприяють об'єктивному аналізу тимчасових проблем у використанні часового ресурсу та формування індивідуальної технології, яка найбільше відповідає характеру, темпераменту, біологічним ритмам та роду занять [8].

Сутність тайм-менеджменту полягає воптимальному використанні ро- 
бочого часу та зменшенні дії факторів, що спричиняють значні втрати часу. Метою вивчення тайм-менеджменту є:

- навчання розподілу і використання робочого часу через розстановку життєвих цілей та пріоритетів для отримання найефективнішого результату окремої діяльності в цілому;

- виявлення і попередження основних причин «нестачі» часу через систему продуманого алгоритму дій та його виконання;

- визначення ефективних стратегій планування та використання часу 3 метою досягнення поставлених цілей та покращення якості життя.

Тайм-менеджмент - це мистецтво ефективно розпоряджатися своїм часом. Час - найцінніший, непоправний ресурс, який розподілено між усіма людьми справедливо. Мотивація є ключем до успіху. Як говорять, займіться улюбленою справою, і вам не доведеться працювати жодного дня у вашому житті. I ще одна вельми поширена причина - невміння організувати роботу i грамотно розпорядитися часом. Саме 3 цією проблемою і покликаний боротися тайм-менеджмент.У відповідності до запропонованого алгоритму перед тим, як планувати та безпосередньо розпочинати виконувати роботу, на думку М. Прищака, керівнику закладу освіту необхідно дати відповіді на чотири запитання [17]:

На думку Н. Любченка, намагаючись впровадити програму таймменеджменту в колектив працівників, важливо пам'ятати, що ця система не така вже й доступна і зрозуміла кожному, тому, відповідно, сприйняти та засвоїти її буде не просто всім співробітникам. Процеси тайм-менеджменту чи управління часом базуються на таких головних принщипах:

- правильна постановка мети (головне аби вона була чітко визначеною та досяжною);

- мотивація (бажання зекономити час повинно бути усвідомленим і пов'язаним із задоволенням якихось важливих потреб);

- результативність (управління часом необхідно для того, щоб зняти чи, принаймні, знизити дефіцит часу, виконуючи певні завдання за коротший період) [14].

Завдання, які вирішує тайм-менеджмент, дозволяють працівникові:

- досягти поставлених цілей, витрачаючи при цьому мінімальну кількість часу;

- домогтися високих результатів у будь-чому (як у роботі, так і в особистому житті);

- раціонально розподіляти свійробочий час, не затримуючись допізна на роботі й, відповідно, мати змогу повноцінно відпочити, залишаючи час на дозвілля й спілкування з близькими;

- збільшити свій матеріальний добробут, якщо є можливість узяти на себе додаткову роботу;

— позбутися стресу та втоми від постійної завантаженості справами;

— мати чіткий кар'єрний план на майбутнє; 
— здійснювати повний контроль над своїм життям.

На сьогоднішній день виділяють два основні напрями таймменеджменту: корпоративний і особистий.

Корпоративний тайм-менеджмент актуальний у закладах освіти i важливий, насамперед, для керівників закладу освіти, які планують графік роботи певного структурного підрозділу чи закладу освіти в цілому. При такому напрямі керівник закладу освіти розподіляє пріоритетність поточних завдань і визначає терміни їх виконання, а потім, залежно від отриманих результатів, вирішує, скільки завдань потрібно на певний проміжок часу поставити перед кожним зі своїх підлеглих i, звісно, контролює їхнє виконання.

Особистий тайм-менеджмент стосується окремої людини і може торкатися як іï професійної діяльності, так і сфери особистого, приватного часу, розвитку, відносин. Особистий тайм-менеджмент актуальний, коли людина «не встигає нічого» - ані нароботі, ані в особистих справах. Якщо працівник постійно відчуває себе втомленим, кожен день ретельно працює,нічого не встигає - це означає, що приділити увагу його взаємодії з часом просто необхідно. Ви можете йому допомогти налагодити раціональне використання часу, але для цього потрібно, аби працівник, по-перше, сам виявив таке бажання, а по-друге, аби він чітко розумів, для чого йому це потрібно.

Тайм-менеджмент спрямований не на те, аби працювати інтенсивніше - це спосіб працювати ефективно й знизити виснаження фізичних $\mathrm{i}$ моральних резервів та підвищити продуктивність праці не за рахунок збільшення зусиль, а за допомогою їх правильного розподілу.

Якщо організація робочого простору була обов'язковою, але підготовчою дією, то безпосереднім початком запровадження тайм-менеджменту буде складання плану робочих завдань (на рік, на місяць та на кожен день). Ïх можна записувати у блокнот, вносити до телефону, використовувати спеціальні програми, алеважливі цілі повинні бути зафіксовані. Цей список слід переглядати і перевіряти на актуальність, редагувати його відповідно до нових завдань, що виникають, а також стежити за ймовірною зміною пріоритетності. Кожне завдання повинно мати фіксовані терміни, час початку і закінчення виконання. Психологічним прийомом стимулювання подальшої діяльності буде позначення галочками або викреслювання виконаних пунктів зі списку.

Звісно, одразу складати плани на великий проміжок часу важко, тому почніть 3 невеликих періодів - одного дня, трьох днів чи, максимум, одного робочого тижня. При цьому надзвичайно важливо не лише виконувати те, що ви запланували, а й робити тільки те, щьо є у вашому списку (звичайно, якщо виникне позаштатна ситуація, коли, приміром, негайно слід виконати якесь незаплановане завдання на вимогу керівництва й неможливо його відкласти «на потім», то виконайте його, але замість нього перенесіть на ін- 
ший день чи тиждень рівноцінне завдання $з$ вашого списку). Завдяки такій стратегії керівник закладу освіти може і не помітити, як з'явиться вільний час на особисті справи. Працюючи саме так, можна зробити день продуктивнішим і лише цей спосіб вже дозволить заощадити близько 25\% робочого часу.

Важливо під час складання плану враховувати пріоритети- завдання та справи краще структурувати, а не просто записувати все, що потрібно зробити за день. Розділяти справи таким чином неважко, потрібно лише звикнути до цього. Варто зазначити, що, незважаючи на доступність усіляких програм для планування, поки що найбільшою ефективністю все ж відзначаються паперові носії - блокноти або щоденники. Це пояснюється вже згаданим психологічним впливом - процесвикреслювання чи виділення певними позначками виконаних пунктів надає почуття задоволення від виконаної роботи.

Цікавим є така загальна особливість, що на початку впровадження в життя планування, майже всі добре уявляють, як буде виглядати початок дня, але мало хто наперед бачить його закінчення. Між тим наприкінці кожного робочого дня має залишатися хвилин 15 для оцінки кінцевого результату —рефлексія, тобто оцінка рівня виконання запланованого обсягу роботи, період для аналізу, що залишилося невиконаним і чому (брак часу, зовнішні незалежні від вас обставини, зміна пріоритетів тощо). Це допоможе надалі коригувати відповідні деталі.

Варто пам'ятати, що свідомість і увага державного службовця можуть ефективно концентруватися і працювати тільки з одним об'єктом: одним завданням, одним документом тощо. Зосередження уваги на кількох завданнях одночасно робить вас менш продуктивним: на все йде більше часу, оскільки ви нічому не приділяєте достатньо уваги, варто зосередитися на одному завданні й таким чином зробити всю роботу швидше, що дозволить більш ефективно використовувати весь ваш час. Керівнику закладу освіти варто навчитися розділяти інформацію на потрібну та непотрібну, заощаджувати час й не тримати в голові неважливі справи. Кожному час від часу доводиться стикатися з нецікавими чи навіть неприємними справами. Багато хто прагне такі справи відсунути якомога далі й свідомо чи несвідомо усіляко ухиляється від їхнього виконання, що збільшує витрати робочого часу. Рано чи пізно потрібно буде вирішувати цю неприємну справу, а часу не лишиться зовсім і обсяг роботи, який необхідно виконати, може збільшитися. Невирішене питання буде переслідувати, поки його не вирішити, а думки про нього будуть викликати все більше роздратування.

Розумне делегування справ дасть можливість позбутися виконання поточних завдань, які можна доручити підлеглим. Це звільнить час керівника закладу освіти для виконання ваших обов'язкових та більш важливих завдань. Головне - правильно сформулювати завдання, яке ви делегуєте, визначивши строк для його виконання. Вигідніше один раз витратити час на 
навчання іншої людиниробити певну справу, ніж постійно виконувати іiї самостійно (особливо, якщо вона не відноситься до основних і цілком може бути виконана підлеглим працівником). Варто опанувати принципи делегування й перекладати на інших певні завдання.Не менш важливу роль у процесі ефективного управління часом грасавтоматизація певних процесів: автоматичне сортування поштових повідомлень, оформлення регулярних онлайн-платежів тощо. Все, що може працювати без вашої безпосередньої участі, додатково зекономить час.

Фактори, які якимось чином відволікають у процесі впровадження тайм-менеджменту, можна умовно розділити на дві категорії:

- зовнішні чинники, коли відволікає хтось або щось (наприклад, особа, яка заходить до вашого кабінету, телефонує чи надсилає смсповідомлення);

- внутрішні чинники, коли ви самі перериваєте роботу (приміром, перевіряєте електронну пошту не у відведений для цього час, йдете випити кави, проглядаєте соціальні мережі)[22].

Із внутрішніми факторами, що відволікають, впоратися дещо складніше, ніж із зовнішніми чинниками - це вже проблема, пов'язана з вашим власним бажанням відволіктися від роботи. Особливо часто це відбувається, коли керівник закладу освіти прагне відкласти роботу «на потім», робити це свідомо, що знижує продуктивність.Боротися з внутрішніми факторами, які відволікають, керівнику закладу освіти допоможуть наступнічинники:

- закрити поштову программу (нехай це вікно буде відкрито тільки у тому випадку, якщо ви свідомо виділили час на перегляд електронної пошти та написання листів-відповідей);

- відключити звукові сигнали й вікна, що спливають (це джерело нескінченних перешкод у роботі, а також ваше «виправдання» перед самим собою, чому ви перериваєте роботу й займаєтеся чимось не дуже потрібним саме зараз);

- переведення мобільного телефону на віброрежим. Беріть слухавку лише у тому разі, коли ви знаєте, хто телефонує, для вас цей дзвінок $є$ важливим і ви впевнені, що розмова займе не більше двох хвилин (якщо це потрібна, але довга розмова, то завчасно відведіть для неї час у своєму розкладі) [22].

Як зазначив В. Свдокимов, у зв'язку з тим, що кожна людина має свої особливості, виникає потреба у формуванні індивідуальної технології управління часом з урахуванням таких механізмів:

- біологічного годинника, від якого залежить те, на яку частину доби припадає максимальна активність людини;

- інтелектуального інжинірингу, під яким розуміють використання знань про людський потенціал і домінантну півкулю мозку;

- психологічного годинника, в якому виокремлюють психологічну часову перспективу, яка включає в себе психологічне теперішнє, минуле й 
майбутнє та сприйняття часу як процесу формування психологічного теперішнього;

- стилю поведінки людини, який відображає моральні та етичні норми особистості та визначає іiі поведінку в різних життєвих ситуаціях [5].

3 урахуванням узагальнення різних наукових підходів до сутності поняття «технологія» ми розглядаємо технологію (від гр. techne - мистецтво, майстерність, уміння та logos - слово, навчання) як змістову техніку реалізації певної діяльності, механізм реалізації якої забезпечується формами, методами та засобами здійснення цієї діяльності й є їі динамічною основою. Автор навчального посібника «Тайм-менеджмент» Л. Скібіцька пропонує певні технології планування робочого часу- використовувати в управлінській діяльності технології ухвалення рішень за пріоритетністю справ. Ухвалення рішення - це фундамент управління і найбільша частка часу (до 80\%) в діяльності керівника пов'язана саме з цим процесом. Керівники, намагаючись постійно виконувати занадто великий обсяг роботи, витрачають свої сили на несуттєві проблеми. Ухвалення рішення передбачає вибір першочергових справ і завдань. Визначити пріоритети означає ухвалити рішення про те, якій справі варто надати першочергове значення. За допомогою опрацювання і реалізації управлінських рішень керівники всіх рівнів здійснюють покладені на них функції [19].

Тайм-менеджмент - це вміння управляти собою із застосуванням відповідних методик та механізмів організації часу, які сприяють об'єктивному аналізу тимчасових проблем у використанні часового ресурсу та формування індивідуальної технології, яка найбільше відповідає характеру, темпераменту, біологічним ритмам та роду занять [2]. Сутність тайм-менеджменту полягає воптимальному використанні робочого часу та зменшенні дії факторів, що спричиняють значні втрати часу. Метою вивчення таймменеджменту є:

- навчання розподілу і використання робочого часу через розстановку життєвих цілей та пріоритетів для отримання найефективнішого результату окремої діяльності в цілому;

- виявлення і попередження основних причин «нестачі» часу через систему продуманого алгоритму дій та його виконання;

- визначення ефективних стратегій планування та використання часу 3 метою досягнення поставлених цілей та покращення якості життя. Аналіз сучасної літератури з проблем управління часомдозволяє згрупувати запропоновані методики та інструменти тайм-менеджменту в п'ять великих груп: інструменти діагностування наявності особистих проблем в управлінні часом; методики планування часу задля досягнення оптимальних результатів; підходи до найкращої організації робочого та життєвого простору; способи управління власними діями та вчинками; найкращі способи постійного самовдосконалення.

Зараз керівники активно використовують спеціальні комп’ютерні та 
телефонні програми, органайзери. Найефективніший спосіб обліку часу - це ведення записів. Причини, які не завжди залежать від керівника: це робота 3 кореспонденцією, великий потік рутинних або термінових справ, а також «крадії часу». Керівник не може позбутися від цих факторів і може лише спробувати максимально зменшити їх вплив на втрати часу. «Крадії часу»це непередбачені справи, більшість з яких вимагають термінового вирішення і не можуть бути передоручені підлеглим. Вони забирають багато часу i відволікають від дійсно важливих справ.Існує багато різних видів «крадїв часу»:

- телефонні дзвінки;

- люди,що заглядають у кабінет та непрошені відвідувачі;

- проблеми з комп'ютерним обладнанням;

- зміна послідовності робіт та доручень, що нав'язуються начальством, колегами, персоналом;

- невдале планування діяльності з урахуванням реалій часу та важливості проблем;

- невміння слухати інших людей;

- незадовільна організаційна структура;

- виправлення помилок минулої роботи, яких можна було б уникнути;

- нерішучість, нестача волі, невміння сказати «ні» у ділових питаннях;

- погано організовані і нескоординовані збори, наради та інші заходи;

- фактори, що відволікають, неприбраність робочого столу;

- надмірна офісна бюрократія;

- даремні дискусії про свою роботу та роботу інших.

Так, у стані постійного поспіху керівник закладу освіти не встигає зосереджуватися на тому завданні, яке він виконує в даний момент. Постійні допрацювання вдома породжують замкнуте коло, коли людина не встигає в робочий час виконати свої справи і вирішити усі проблеми, в результаті вона змушена вирішувати їх вдома за рахунок свого вільного часу, відпочинку та особистого життя.

На думку С. Павлютенкова, тайм-менеджмент як система управління часом вимагає від керівника закладу освіти врахування певних етапів, які в сукупності дозволяють раціонально використати необхідний для здійснення управлінської діяльності час, серед яких:

- аналіз використовуваного робочого часу;

- формування стратегії за підсумками проведеного аналізу;

- постановка мети, яку планує досягти керівник при використанні технології управління часом;

- планування робочого часу і визначення пріоритетів;

- реалізація - конкретні дії, відповідно до запланованого;

- систематичний контроль досягнення мети, виконання планів, раціонального використання часового ресурсу [15]. 
Слід відмітити, що науковець Кук М. поєднує тайм-менеджмент 3 набором методик, способів і технологій, які дають можливість здійснювати розподіл особистого часу з метою підвищення ефективності його використання. Вважаємо, що раціоналізація діяльності керівника ЗНЗ може бути підвищена засобами використання певних технологій тайм-менеджменту, які дозволяють швидко їх освоювати і використовувати окремо або в поєднанні. 3 урахуванням узагальнення різних наукових підходів до сутності поняття "технологія" ми розглядаємо технологію (від гр. techne - мистецтво, майстерність, уміння та $\operatorname{logos}$ - слово, навчання) як змістову техніку реалізації певної діяльності, механізм реалізації якої забезпечується формами, методами та засобами здійснення цієї діяльності й є ії динамічною основою [12].

Отже, впровадження технології тайм-менеджменту в практичній діяльності керівника закладу освіти дасть змогу:

- підвищити продуктивність і результативність повсякденної діяльності;

- значно зекономити час і підвищити коефіцієнт використання робочого часу;

- досягти значних результатів за рахунок економії часу;

- скоротити кількість та обсяг виконуваних справ за рахунок ефективного планування робочого часу;

- чітко розставити пріоритети;

- покращити терміни виконання проєктів;

- зменшити кількість відтермінованих завдань;

- поліпшити якість робіт за завданнями і проєктами.

Висновки.Таким чином, для досягнення успіху державним службовцям необхідно постійно підвищувати ефективність - власну та своїх підлеглих. Досягти цього можна за допомогою управління часом - таймменеджменту. У зв'язку з тим, що жодна із систем тайм-менеджменту не $\epsilon$ універсальною, для розв'язання проблем з управління часом необхідні знання широкого спектру та вміння використовувати різні підходи. Грамотна організація часу роботи державних службовців дає змогу досягати глобальної мети та стати більш успішним у всіх напрямах управлінської діяльності.

\section{Список використаних джерел:}

1. Алюшина Н. О. Тайм-менеджмент: Мистецтво планувати та управляти своїм часом. Київ : Національна академія державного управління при Президентові України, 2008. 119 с.

2. Архангельский Г., Лукашенко М., Телегина Т, Бехтерев С. Таймменеджмент. Полный курс: учебное пособие. Москва: Альпина Паблишер, 2012. $311 \mathrm{c}$.

3. Берд П. Тайм-менеджмент: Планирование и контроль времени. [пер. с англ. К. Ткаченко]. М. : ФАИР-ПРЕСС,.2004. 288 с.

4. Бишов А. Самоменеджмент. Ефективно і раціонально. М: Омега-Л, 2005. $125 \mathrm{c}$. 
5. Свдокимов В.О. Основи плануваннятайм-менеджменту державних службовців. Теорія та практика державного управління. URL: http://nbuv.gov.ua/UJRN/Tpdu_2016_2_31

6.Євтушенко Г. І. Аналіз стану управління робочим часом та шляхи підвищення ефективності застосування «Тайм-менеджменту» в організації / Збірник наукових праць Національного університету державної податкової служби України . 2014. №1. С. 88-96.

7. Заєць Н. Ю. Вплив тайм-менеджменту керівника на розвиток позитивного іміджу загальноосвітнього навчального закладу. 2017. URL: file:///C:/Users/Home/Downloads/VchdpuP_2017_142_12.pdf

8. Заєць Н. Ю. Вплив тайм-менеджменту керівника на розвиток позитивного іміджу загальноосвітнього навчального закладу / Вісник. Серія: Педагогічні науки. 2017. № 142. С. 45-50.

9. Калініченко Л. Л. Особливості впровадження тайм-менеджменту на підприємстві / «Молодий вчений». 2017. № 4.4 (44.4). С. 60-63.

10. Кук М. Эффективный тайм-менеджмент: Как рационально планировать свое рабочее и свободное время [пер. с англ. К. Давыдовой]. М.: ФАИР-ПРЕСС, 2003. $336 \mathrm{c}$.

11. Любченко Н. В. Тайм-менеджмент в освітній установі: спецкурс. Управління науково-методичною діяльністю закладів післядипломної педагогічної освіти: координаційний аспект: наук.-метод. посіб. / ред. кол.: С. Р. Чернишова; НАПН України, Ун-т менедж. освіти. Київ : ЦП «КОМПРИНТ», 2013. С. 221-232.

12. Павлютенков Є. М. Професійна компетентніть директора школи. / Управління школою. 2003. № 7. (19) березня. С. 2-4.

13.Писаревська Г. Використання тайм-менеджменту для підвищення ефективності управління персоналом. Науковий вісник Херсонського державного університету. Серія «Економічні науки». 2016. Вип. 20. Ч. 1. С. 148-153.

14.Скібіцька Л. І. Організація праці менеджера : навчальний посібник. Київ: Центр учбової літератури. 2010. 360 с.

15.Скібіцька Л. І. Тайм-менеджмент: навч. посіб. для студ. екон. вузів / Київ: Кондор, 2009. 528 с.].

16.Тайм-менеджмент - наука сучасності URL: http://womanonly.ru/psihologija_i_karera/psihologija/tajm-menedzhment_ nauka_sovremennosti

17.Тайм-менеджмент, або мистецтво управління часом URL: https://vseosvita.ua/library/tajm-menedzment-abo-mistectvo-upravlinnacasom42519.html

18.Функции тайм-менеджмента.

http://knowledge.allbest.ru/managem...._0.html.

\section{References:}

1. Alyushina N.O (2008) Time Management: The art of planning and managing your time [Pidruchnyk $\mathrm{z}$ taim-menedzhmentu] National Academy of Public Administration under the President of Ukraine, Kyiv, Ukraine

2. Arkhangelsky G., Lukashenko M., Telegina T, Bekhterev S. (2012) Time management. Full course: textbook. [Taim-menedzhment. Polnыi kurs: uchebnoe posobye] Alpina Publisher, Moscow 268 
3. Byrd P.(2004) Time Management: Time Planning and Control. [Pidruchnyk z taim-menedzhmentu] FAIR-PRESS, Moscow

4. Bishov A. (2005) Self-management. Efficiently and rationally.[Pidruchnyi z samomenedzhmentu] Omega-L, Moscow

5. Evdokimov $\mathrm{VO}(2016)$ Fundamentals of time management planning for civil servants. Theory and practice of public administrationavailable at: https: http://nbuv.gov.ua/UJRN/Tpdu_2016_2_31(Accessed 07 May 2021).

6. Yevtushenko GI (2014) Analysis of the state of working time management and ways to increase the effectiveness of "Time Management" in the organization Collection of scientific works of the National University of the State Tax Service of Ukraine [ZbirnyknaukovykhpratsNatsionalnohouniversytetuderzhavnoipodatkovoisluzhbyUkrainy]Irpen, Ukraine

7. Zayets N. Yu.(2017) Influence of time management of the head on the development of a positive image of a secondary schoolavailable at: https: file:///C:/Users/Home/Downloads/VchdpuP_2017_142_12.pdf(Accessed 07 May 2021).

8. Zayets N. Yu. (2017) Influence of time management of the head on the development of a positive image of a secondary school / Visnyk. Series: Pedagogical sciences [Visnyk. Series: Pedagogical sciences], Kiev, Ukraine

9. Kalinichenko LL (2017) Peculiarities of time management implementation at the enterprise / "Young scientist" [Osoblyvosti vprovadzhennia taim-menedzhmentu na pidpryiemstvi / «Molodyi vchenyi»], Kiev, Ukraine

10. Cook M. (2003) Effective time management: How to rationally plan your work and free time [Pidruchnyk z taim-menedzhmentu]. FAIR-PRESS, Moscow

11. Lyubchenko NV (2013) Time management in an educational institution: special course. Management of scientific and methodical activity of institutions of postgraduate pedagogical education: coordination aspect: scientific method. way.[Pidruchnyk z taim-menedzhmentu]. NAPS of Ukraine, education.University of Managemen, Kyiv, Ukraine

12. Pisarevska G. (2016) Using time management to increase the efficiency of personnel management. Scientific Bulletin of Kherson State University. Economic Sciences Series[Naukovyi visnyk Khersonskoho derzhavnoho universytetu. Seriia «Ekonomichni nauky»]Kherson, Ukraine

13. Skibitska LI (2010) Organization of manager's work: textbook. [Orhanizatsiia pratsi menedzhera: navchalnyi posibnyk] Center for Educational Literature, Kyiv, Ukraine

14. Skibitska LI (2009) Time Management: textbook. way. for students. econ. of universities [Time Management: textbook. way. for students. econ. of universities] Condor, Kyiv, Ukraine

15. Time management is a modern science available at: https: http://womanonly.ru/psihologija_i_karera/psihologija/tajm-menedzhment__ nauka_sovremennosti(Accessed 07 May 2021).

16. Time management, or the art of time managementavailable at: https:https://vseosvita.ua/library/tajm-menedzment-abo-mistectvo-upravlinnacasom42519.html(Accessed 07 May 2021).

Time management functionsavailable at: https:http://knowledge.allbest.ru/managem...._0.html(Accessed 07 May 2021). 